Vol. 9 (2): 297-304 (2019)

\title{
BIO-MONITORING OF NARTA LAGOON
}

\author{
Rudina Koçi ${ }^{*}$, Alma Imeri², Lirika Kupe ${ }^{3}$, Marsela Alikaj ${ }^{4}$ \\ ${ }^{1 * 2,3,4}{ }^{4}$ gricultural University of Tirana, Faculty of Agriculture and Environment, Tirana, Albania; \\ *Corresponding author Rudina Koçi author: rudikoci@gmail.com;
}

Received March 2019; Accepted April 2019; Published May 2019;

DOI: https://doi.org/10.31407/ijees9209

UOI license: http://u-o-i.org/1.01/ijees/63321254

\begin{abstract}
Narta is considered as one of the most important lagoon areas in Albania based on the high biodiversity values and the number of habitats found there. The natural ecosystem of Narta is characterized by a rich diversity of habitats as lagoon area, delta of Vjosa River, salt marshes, sand dunes, pine forest, islet of Zverneci. The relations between these various types of habitats are of great ecological importance. The studies for this area have shown the importance of the area related to the interesting and specific flora. In the vast variety of habitats, many of the plants species that occur are specifically and uniquely found in this coastal area. Level of trophic state is based on standard methods for analysis of macrophytic vegetation and chlorophyll a, dissolved oxygen (DO) and biological oxygen demand (BOD), Phosphor contents. Also, are measured physic characteristics of waters like temperature, Ph. Plant communities' evaluation is based on qualitative and quantitative characteristics and is classified through principals of Zurich-Montpellier school. Monitoring of chlorophyll a content, dissolved oxygen (DO) and biological oxygen demand (BOD), phosphor contents, and macrophytes species are carried out during a year from April to September 2018. In Lagoon are selected four stations for samples taking. Evaluation of water trophic level is based on classification proposed by Hắkannson [4]. Oligotrophic: clear and blue water, with very low levels of nutrients and algae. Mesotrophic: slightly green water, still clear, moderate levels of nutrients and algae. Eutrophic: green and murky water, with higher amounts of nutrients and algae. Hypertrophic: supersaturated in phosphorus and nitrogen, excessive phytoplankton growth, poor water clarity. Flora of Narta Lagoon belongs to the aquatic macrophytes rooting in sediment. Two main groups are commonly distinguished: Zoostera and Rupia.The aquatic vegetation strongly influences the light conditions, temperature, oxygen concentration, sedimentation rate and turbulence in the water body. Analyses for determination of dissolved oxygen (DO) and biological oxygen demand (BOD) are realized through Winkler method. Based on the collected data we can evaluate that Narta Lagoon is characterized by Mesotrophic state level.
\end{abstract}

Key words: macrophytes, trophyc state, Chl a, BOD, DO. 